\section{DISTORY: PENGEMBANGAN KAMUS DIGITAL SEJARAH BERBASIS VISUAL BASIC PADA MATERI KERAJAAN TARUMANEGARA}

\author{
Muhammad Rofiul Alim \\ mralim@mankotabatu.sch.id
}

Madrasah Aliyah Negeri Kota Batu, Indonesia.

Abstract: The transformation of learning in the 21st century requires an
adjustment between the development of science and technology.
Learning sources are part of the learning system that is transformed
from conventional learning sources into digital-based learning sources.

\section{RIDSI}

ARTICLE INFO:

Research Article

Article history:

Received 19 February 2021

Revised 26 March 2021

Accepted 27 March 2021

Published 16 June 2021

Available online 16 June 2021

(C)2021. Muhammad Rofiul Alim. All rights reserved. Digital-based learning sources are considered more practical than conventional learning sources. Digital-based learning sources can be applied to history, which many students get bored easily when studying. Therefore, the aim of this study is to develop a digital-based learning source for history that makes it easier for students to study it. Digital History Dictionary (Distory) is an application of a digital-based learning source that has been developed based on learning requirement analysis. Distory also can make it easier for students to find and learn history. The main purpose of the development of Distory is an innovation of digital-based historical learning sources that is economical, practical, flexible, and appropriate with learning objectives. The research methodology used in the research and development of Distory, was based on Sugiyono's research model, namely: (1) potential and problems; (2) data collection; (3) product design; (4) design validation; (5) design revision; (6) small class trials; (7) product revision; (8) large class trials; (9) product revision; and (10) mass production. Distory is validated by experts as a basis for product improvement before field trials are carried out. Small and large class trials were carried out on the students of Madrasah Aliyah Negeri (MAN) Batu. The results of the validation of media experts, small class trials, and large class trials were 85 percent, 88.75 percent, and 89 percent, respectively. Based on these results, the development of Distory can be categorized as very decent and ready to be implemented.

Keywords: 21st Century Learning, Learning Sources, Digital History Dictionary

\title{
PENDAHULUAN
}

Belajar pembelajaran di era digital menuntut proses perencanaan, pelaksanaan, dan penilaian dilaksanakan secara efektif dan efisien. Proses belajar menjadikan pribadi lebih baik dan memiliki 
kemampuan mengatasi masalah individu dan sekitarnya (Sitepu, 2014). Proses belajar pembelajaran memanfaatkan teknologi di era digital diharapkan menjadi solusi dan inovasi terhadap masalah ditemukan di lapangan. Penggunaan teknologi pada bidang pendidikan saat ini menjadi wajar mengingat kemajuan ilmu pengetahuan dan teknologi (IPTEK) terus berkembang. Optimalisasi teknologi untuk belajar pembelajaran diharapkan meningkatkan kualitas proses belajar pembelajaran dan secara kuantitas terwujudnya pemerataan pendidikan di Indonesia. Pembelajaran jarak jauh berbasis website (elearning) dan evaluasi dengan aplikasi Computer Assisted Test (CAT) Online sebagaian contoh dari inovasi dan pemanfaatan teknologi pada bidang pendidikan. Pembelajaran di era digital tidak harus dilaksanakan secara konvensional namun dapat dilaksanakan dengan jarak jauh (Alim dan Puspitasari, 2021).

Sumber belajar merupakan salah satu bagian penting dalam sistem belajar dan pembelajaran yang diharapkan berinovasi dengan berkembangnya ilmu pengetahuan dan teknologi di era digital. Pemanfaatan sesuatu untuk sumber, bahan, dan pengalaman belajar sehingga mencapai tujuan hakikat dari sumber belajar (Sanjaya, 2011). Peran sumber belajar dinilai penting dalam proses belajar sebagai sumber belajar, sumber alat, dan sumber peraga dalam proses belajar (Musfiqon, 2012). Sumber belajar berbasis digital dinilai lebih memiliki keunggulan tersendiri seperti halnya saat berlangsungnya pembelajaran jarak jauh (PJJ).

Konsep kamus digital didasarkan pada observasi pertama pada bulan 16-22 November 2020 semester 1 tahun pelajaran 2020/2021 di semua kelas X di Madrasah Aliyah Negeri (MAN) Kota Batu saat pembelajaran jarak jauh (www.elearningmakoba.sch.id). Peserta didik cenderung memilih sumber atau bahan belajar berbasis digital, yang memiliki sifat praktis dan tidak berat saat dibawa serta tidak menyita tempat. Sumber belajar berbasis digital memudahkan peserta didik daring untuk belajar dan bahkan bagi peserta didik luring yang terkendala internet, cukup copy file ke flashdisk diakses secara offline. Faktor pendukung kecenderungan pemilihan kamus digital mudah mencari keywords materi yang ingin di pelajari seperti penggunaan aplikasi digital Kamus Besar Bahasa Indonesia (KBBI). Sumber belajar berbasis digital lebih menyenangkan dan sesuai dengan jiwa zaman peserta didik. Observasi kedua dengan kuesioner dan wawancara peserta didik kelas X MIPA 4 pada 19 Januari 2021 dan kelas X IPS 2 pada 23 Januari 2021 saat belajar mata pelajaran sejarah Indonesia menemui kesulitan memahami materi kerajaan masa Hindu Budha terutama pada materi Kerjaan Tarumanegara yang dinilai terdapat cukup banyak materi prasasti-prasasti. Hal ini di dukung dengan tugas harian pada materi kerajaan Hindu Budha yang banyak dibawah nilai 80. Masalah tersebut tidak lepas dari kurangnya motivasi peserta didik membaca buku sejarah yang dirasa tebal dan membosankan. Hasil observasi juga menunjukkan diperlukannya sumber belajar untuk sejarah berbasis digital sehingga praktis dan menarik. Sehingga diperlukan inovasi sumber belajar yang memudahkan belajar materi sejarah dan menarik. Kamus adalah salah satu bentuk dari sumber belajar yang dibutuhkan dalam pendampingan proses belajar. Perkembangan era digital menjadikan kamus yang dulunya berbentuk cetak, tebal, dan berat menjadi lebih praktis dengan bentuk digital. Konsep kamus digital menjadi lebih efektif dari pada katalog digital dengan sistem pencariannya, sedangkan katalog dinilai tidak jauh berbeda dengan tampilan buku digital pada umumnya. 
Pengembangan kamus digital dapat dikembangkan secara offline dan online untuk perangkat sistem operasi smartphone dan komputer. Namun penggunaan smartphone sebagai sumber belajar pada waktu pembelajaran di kelas menjadi terkendala menginggat di beberapa sekolah melarang penggunaan smartphone selama proses belajar. Hal tersebut diberlakukan karena dinilai lebih sulit mengontrol penggunaan smartphone dan lebih mudah mengontrol penggunaan komputer oleh peserta didik. Program aplikasi kamus digital untuk sistem operasi komputer dapat dikembangkan salah satunya menggunakan bahasa pemrograman beginners all purpose symbolic-instruction code lebih dikenal dengan istilah BASIC. Microsoft visual basic merupakan salah satu aplikasi menggunakan Bahasa pemrograman beginners all purpose symbolic-instruction code, yang memiliki tampilan sederhana dan mudah digunakan untuk merancang dan membuat aplikasi sekalipun bagi pemula.

Digital History Dictionary (DISTORY) merupakan produk pengembangan sumber belajar berbentuk kamus digital sejarah dengan bahasa pemograman basic. Penelitian dan pengembangan terbaru terkait kamus pada mata pelajaran sejarah dilaksanakan oleh Ramadani dan Ofianto tahun 2019 dengan judul "Pengembangan Kamus Mnemonic sebagai Sumber Belajar Sejarah Indonesia di Sekolah Menengah Atas". Persamaan kamus dikembangkan sama-sama untuk mata pelajaran sejarah di jenjang pendidikan SMA/MA. Perbedaan Kamus Mnemonic diklasifikasikan berdasarkan materinya dengan abjad dari A sampai Z untuk mempermudah dalam pencarian, sedangkan Distory menggunakan menu pencarian dengan keywords. Penyusunan komponen Kamus Mnemonic dengan program Microsoft Word 2007, sedangan Distory menggunakan program Microsoft visual basic. Keunggulan dan keunikan Distory berbentuk aplikasi yang bersifat portable dan memiliki menu pencarian yang lebih cepat dalam pencarian materi.

Tujuan utrama dari pengembangan Distory sebagai inovasi sumber belajar sejarah yang berbasis digital yang memiliki nilai ekonomis, praktis, fleksibel, dan sesuai tujuan pembelajaran sejarah. Aplikasi Distory dirancang dan dikembangkan bersifat portable sehingga tanpa proses install setiap penggunaan kamus pada komputer yang berbeda. Sifat portable bertujuan selain mudah digunakan dan tidak diperlukan install saat penggunaannya, dapat disimpan dan dibuka secara langsung dari flashdisk. Hal ini dapat digunakan oleh peserta didik yang memanfaatkan fasilitas komputer sekolah karena tidak memiliki komputer pribadi.

\section{METODE}

Metode penelitian aplikasi kamus Distory menggunakan sepuluh langkah dalam penelitian dan pengembangan dari a) potensi dan masalah, b) pengumpulan data, c) desain produk, d) validasi desain, e) revisi desain, f) uji coba kelas kecil, g) revisi produk, h) uji coba kelas besar, i) revisi produk, dan j) produksi masal (Sugiyono, 2008).

Langkah pertama, identifikasi potensi dan masalah didapatkan dari observasi dan wawancara dengan peserta didik kelas X MIPA 4 dan X IPS 2 di Madrasah Aliyah Negeri (MAN) Kota Batu. Masalah ditemukan selama pembelajaran jarak jauh pada peserta didik yang pertama, kurangnya tertarik terhadap sumber belajar sejarah cetak yang dinilai kurang praktis. Kedua, kesulitannya 
peserta didik dalam memahami materi khususnya pada Kerajaan Tarumanegara. Kurangnya minat untuk membaca sumber belajar sejarah yang dianggap membosankan dan tebal menjadi faktor pendukung. Potensi terlihat pada ketertarikan peserta didik terhadap sumber belajar berbasis digital yang dinilai praktis dibandingkan sumber belajar cetak.

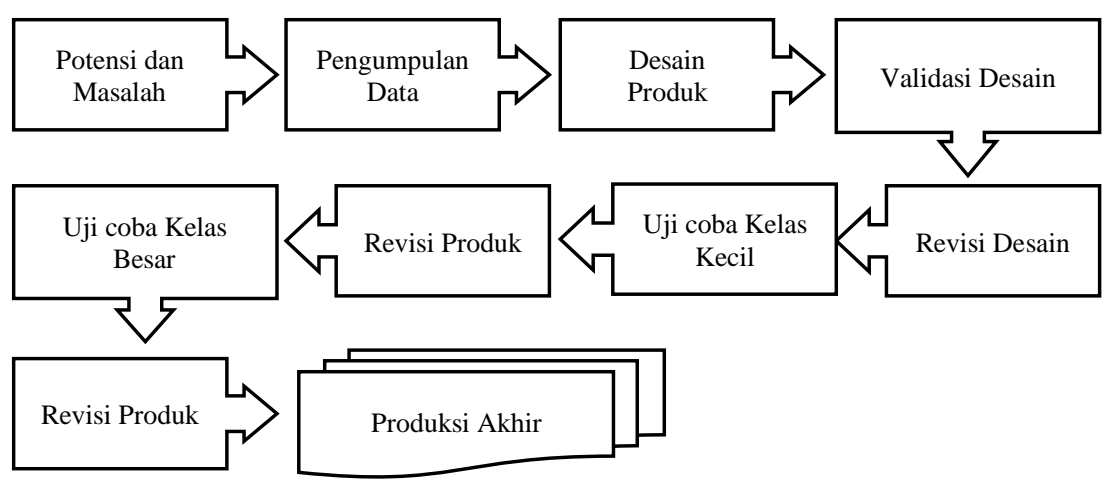

Gambar 1. Model research and development Sugiyono (Sugiyono, 2008)

Berdasarkan statistik elearning selama semester 1 terdapat 379 akses pada e-Modul Pembelajaran Sejarah Kelas X. Data pembaca pada materi sejarah di blog pembelajaran sejarah (www.mr-alim.blogspot.com) selama pjj semester 1 akses terendah 114 view dan akses tertinggi 592 view setiap postingan materi pertemuan. Selain statistik pembaca sumber belajar digital, pekerjaan tugas peserta didik didominasi dengan pemanfaatan aplikasi digital. Sumber belajar digital lebih diminati dan dinilai praktis dari pada sumber belajar cetak, tentu hal ini tidak terlepas dari situasi pembelajaran jarak jauh. Pada langkah kedua, pengumpulan data dilakukan secara online menggunakan google form sebagai lembar kuesioner untuk mengetahui pendapat peserta didik kelas X MIPA 4 dan X IPS 2 di Madarasah Aliyah Negeri (MAN) Kota Batu terkait seberapa diperlukan kamus digital sejarah sebagai sumber belajar.

Langkah ketiga, desain produk yang akan dikembangkan berdasarkan analisis pengumpulan data kebutuhan. Produk aplikasi Distory di desain dengan tampilan menarik sesuai usia peserta didik dan navigasi menu aplikasi yang mudah digunakan. Materi aplikasi tentang Kerajaan Tarumanegara merujuk dari buku Sejarah Nasional Indonesia jilid II edisi pemutakhiran tahun 2010 yang merupakan buku rujukan (babon) sejarah nasional. Langkah keempat, validasi aplikasi Distory oleh ahli media dilakukkan sebelum uji coba lapangan. Validasi materi tidak dilakukan dikarena pertimbangan waktu dan sumber materi sudah merujuk pada buku Sejarah Nasional Indonesia Jilid II. Validasi desain dilakukan oleh ahli media yang memiliki kompetensi bidang teknologi dan pembelajaran. Validator media berprofesi dosen Jurusan Sistem Informasi, Universitas Negeri Jember yakni Bapak Muhammad 'Ariful Furqon, S.Pd., M.Kom. Langkah kelima, revisi desain dilakukan setelah validasi desain produk dari penilaian, kritik dan saran ahli media. Hasil validasi dan revisi produk dengan teliti memiliki pengaruh terhadap proses dan hasil uji coba lapangan. 
Langkah keenam, uji coba dilaksanakan di kelas 10 MIPA 4, Madrasah Aliyah Negeri (MAN) Kota Batu dengan jumlah 10 peserta didik sebagai uji coba kelas kecil. Uji coba produk pada kelompok kecil dilaksanakan secara online, link aplikasi download dan kuesioner diberikan melalui elearning madrasah yang selanjutnya hasil uji coba kelas kecil untuk evaluasi dan perbaikkan produk Distory. Langkah ketujuh, revisi produk yang perlu dievaluasi dan diperbaiki pasca uji coba kelas kecil. Revisi setelah uji coba kelas kecil dilakukan untuk mendapatkan produk lebih baik dari sebelumnya berdasarkan data uji coba kelas kecil. Langkah kedelapan, setelah revisi produk uji coba kelas besar selanjutnya uji coba kelas besar sebagai alat ukur untuk mengetahui tingkat kelayakan produk aplikasi kamus digital sejarah. Uji coba kelas besar dilaksanakan di kelas 10 IPS 2, Madrasah Aliyah Negeri (MAN) Kota Batu. Uji coba kelas besar dilakukan untuk mengukur tingkat kelayakan produk dengan subjek uji coba 30 peserta didik. Langkah kesembilan, revisi produk berdasarkan analisis hasil uji coba kelas besar. Langkah terakhir sebelum benar-benar produk dinyatakan valid atau tidak valid untuk dilaksanakan produksi masal. Langkah kesepuluh, tahap terakhir merupakan produksi masal. Produk aplikasi Distory diproduksi masal sesuai kebutuhan dan perbaikan berdasarkan serangkaian uji coba dan revisi.

Instrumen pengukuran dan pengumpulan data dengan kuesioner validasi penelitian dan pengembangan produk menggunakan skala Likert. Empat kriteria digunakan dinilai lebih efektif dari pada lima kriteria untuk menghindari responden yang lebih cenderung memilih ragu-ragu/kadangkadang/netral (Arikunto, 2013). Beriku skala penilaian Linkert:

Tabel 1. Skala penilaian Likert

\begin{tabular}{cl}
\hline Kriteria & \multicolumn{1}{c}{ Keterangan } \\
\hline Angka 4 & sangat tepat/sangat menarik/sangat layak/sangat sesuai. \\
Angka 3 & tepat/menarik/layak/sesuai. \\
Angka 2 & kurang tepat/kurang menarik/kurang layak/kurang sesuai. \\
Angka 1 & tidak tepat/tidak menarik/tidak layak/tidak sesuai. \\
\hline
\end{tabular}

Instrumen ahli media berisikan tentang aplikasi kamus digital sejarah yang terdiri dari tampilan, tulisan, kemudahan dan aspek yang mendukung media. Berikut adalah kisi-kisi instrumen yang dikembangkan peneliti untuk digunakan instrumen validasi ahli media:

Tabel 2. Kisi-kisi instrumen untuk ahli media

(sumber: instrumen dikembangkan peneliti)

\begin{tabular}{|c|c|c|c|}
\hline Aspek & Indikator & No Butir & Jumlah Soal \\
\hline \multirow[t]{3}{*}{ Tampilan } & Kemenarikan tampilan & 1 & 3 \\
\hline & Kesesuaian tampilan warna & 2 & \\
\hline & Ketepatan tata letak gambar & 3 & \\
\hline \multirow[t]{3}{*}{ Tulisan } & Ketepatan jenis huruf & 4 & 3 \\
\hline & Ketepatan ukuran huruf & 5 & \\
\hline & Ketepatan warna huruf & 6 & \\
\hline \multirow[t]{2}{*}{ Menu } & Ketepatan letak menu & 7 & 2 \\
\hline & Kesesuaian menu dengan isi & 8 & \\
\hline Kemudahan & Kemudahan pengoperasian & 9 & 1 \\
\hline Lain-lain & Compatible windows $7,8,10$ & 10 & 1 \\
\hline
\end{tabular}


Instrumen untuk pengguna atau subjek coba kelas kecil dan kelas besar terdiri dari tiga aspek yaitu kemenarikan, kemudahan, dan kemanfaatan terhadap aplikasi kamus digital sejarah. Berikut kisi-kisi instrumen yang dikembangkan peneliti untuk digunakan untuk subjek coba:

Tabel 3. Kisi-kisi instrumen untuk subyek coba

(sumber: instrumen dikembangkan peneliti)

\begin{tabular}{clcc}
\hline \multicolumn{1}{c}{ Aspek } & \multicolumn{1}{c}{ Indikator } & No Butir & Jumlah Soal \\
\hline Kemenarikan & Kemenarikan aplikasi kamus & 1 & 3 \\
& Kesesuaian tampilan (warna, huruf dan tata letak) & 2 & 3 \\
& Kejelasan tampilan dan teks & 4 & 4 \\
Kemudahan & Kemudahan aplikasi portable & 5 & 6 \\
& Kemudahan pengoperasian & 7 & 3 \\
& Kemudahan mendapatkan informasi & 8 & 3 \\
& Kemudahan menjalankan web pembelajaran & 10 & 9 \\
\hline
\end{tabular}

Instrumen ahli media dan subjek coba dikembangkan sendiri peneliti berdasarkan media dan sumber belajar yang dikembangkan. Hal dikarenakan pengembangan produk, bahasa pemrograman, dan tujuan yang berbeda-beda dari setiap penelitian dan pengembangannya. Indikator kisi-kisi disesuaikan tujuan pengembangan, karakter mata pelajaran, karakter peserta didik, dan jenis media.

Analisis data untuk penelitian dan pengembangan dilaksanakan setelah terkumpul data-data dari hasil uji coba kelas kecil dan kelas besar yang dilaksanakan secara online. Data kualitatif didapat dari hasil penilaian, kritik dan saran ahli media dan subjek uji coba yang selanjutnya sebagai bahan evaluasi untuk mendapat produk yang sesuai dan valid. Sedangkan data kuantitatif didapatkan dari setiap aspek instrumen yang dihitung dengan menggunakan teknik analisis dan nilai mean. Sehingga dapat dirumuskan teknik penghitungan nilai mean sebagai berikut.

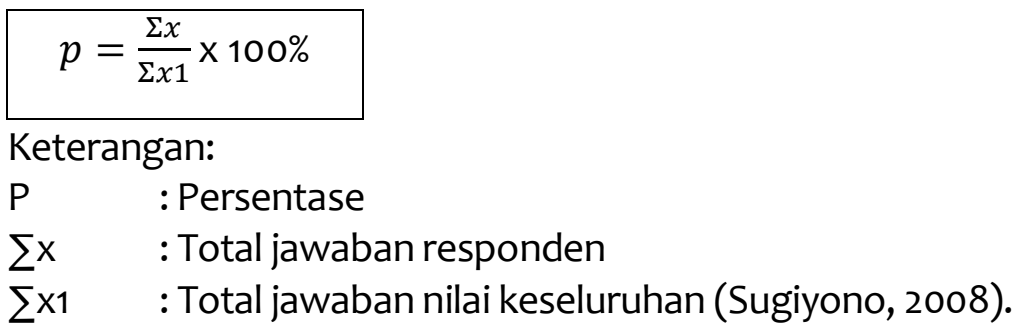

Hasil pengukuran nilai mean dari ahli media, kelas kecil, dan besar. Hasil pengukuran dapat dilihat dalam kriteria validasi sebagai alat ukur kelayakan produk yang dikembangkan. Kriteria validasi produk terbagai menjadi empat kategori yakni sangat layak, layak, cukup layak, dan kurang layak (Sugiyono, 2008).

Tabel 4. Kriteria validasi produk hasil instrumen

\begin{tabular}{cccc}
\hline Kategori & Persentase & Kualifikasi & Tindak Lanjut \\
\hline 1 & $85 \%-100 \%$ & Sangat Layak & Implementasi \\
2 & $74 \%-84 \%$ & Layak & Implementasi \\
3 & $55 \%-74 \%$ & Cukup Layak & Revisi \\
4 & $<55 \%$ & Kurang Layak & Diganti \\
\hline
\end{tabular}




\section{HASIL DAN PEMBAHASAN}

\section{Distory: Kamus Digital Sejarah Sebagai Sumber Belajar}

Penelitian dan pengembangan Distory sebagai kamus digital sejarah bertujuan untuk mengembangkan sumber belajar sejarah untuk peserta didik di Madrasah Aliyah Negeri (MAN) Kota Batu. Pertama, Distory dikembangkan mengacu pada observasi awal 16-22 November 2020 tentang peserta didik lebih memilih sumber belajar digital. Keadaan pandemi dengan pembelajaran jarak jauh juga menjadi faktor penunjang peserta didik lebih memilih sumber belajar digital. Observasi kedua dengan kuesioner dan wawancara peserta didik di kelas X MIPA 4 dan X IPS 2 pada 19 dan 23 Januari 2021 dengan google form untuk mengetahui apakah diperlukan atau tidak kamus digital sejarah sebagai sumber belajar. Hasil kuesioner dari 46 responden dari 60 keseluruhan peserta didik di kelas X X MIPA 4 dan X IPS 2, menunjukkan sangat tidak diperlukan: 0 (0\%), tidak diperlukan: 2 (4.3\%), diperlukan: 20 (43.5\%), dan sangat diperlukan 24 (52.2\%). Sedangkan 14 lainnya tidak mengisi kuesioner dan sebagian peserta pembelajaran luring.

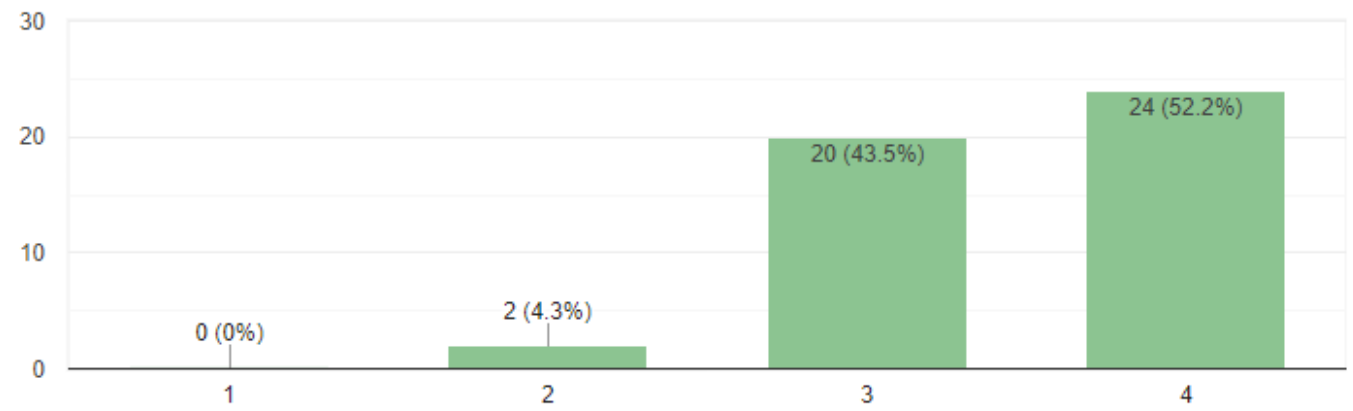

Gambar 2. Diagram Hasil Observasi X MIPA 4 dan X IPS 2

Data observasi di X MIPA 4 dan X IPS 2 menunjukkan diperlukannya aplikasi kamus digital sejarah sebagai sumber belajar sejarah berbasis digital. Inovasi sumber belajar sejarah dalam bentuk digital dinilai lebih praktis dan tentu dalam keadaan pembelajaran jarak jauh. Dengan demikian, diperlukan adanya sumber belajar yang variatif dan dapat dipakai oleh peserta didik untuk memudahkan belajar (Hamalik, 1994).

Kedua, Distory dikembangkan dengan kriteria umum sumber belajar yang ekonomis, praktis, mudah diperoleh, fleksibel dan komponen sesuai tujuan. Bernilai ekonomis dan mudah diperoleh dikarenakan Distory sebagai sumber belajar diperoleh secara gratis. Nilai praktis dan fleksibel dikarenakan kamus berbentuk digital dan portable. Distory sebagai sumber belajar dikembangkan berdasarkan temuan dan indikator rencana pelaksanaan pembelajaran. Sumber belajar dikembangkan harus memiliki tujuan yang jelas, dari aspek memotivasi, aspek pembelajaran, aspek penelitian (observasi, analisis, dan dicatat secara teliti), pemecahan masalah, dan presentasi (penggunaan alat, pendekatan dan metode, dan serta strategi pembelajaraan)(Rusman, 2009). 
Ketiga, Distory memenuhi aspek kebermanfaatan bagi pendidik dan peserta didik. Bagi pendidik dapat menghemat waktu tatap muka, pendidik berperan menjadi fasilitator, pembelajaran lebih efektif dan interaktif. Sedangkan bagi peserta didik dapat belajar secara mandiri, belajar lebih fleksibel, belajar sesuai daya tangkap terhadap materi, belajar dengan gaya belajar masing-masing, memunculkan potensi peserta didik, dan menjadi pedoman peserta didik untuk belajar (Prastowo, 2018). Inovasi sumber belajar membantu peserta didik dalam mencari materi dengan menuliskan keywords. Hal ini memberikan kesan kepada peserta didik bahwa sejarah menarik dan bukan pelajaran hafalan. Idealnya belajar sejarah bertujuan melahirkan kesadaran hakekat perkembangan budaya dan peradaban manusia dikenal dengan istilah historical consciousness (Sayono, 2015).

\section{Menu dan Desain Distory}

Desain Distory sebagai sumber belajar tersedia dua menu yakni, menu kamus digital istilah sejarah dan menu browser pembelajaran. Halaman awal atau halaman pembuka selamat belajar sejarah, berisikan logo Distory, kolom nama pengguna, tombol masuk, dan keluar. Kolom nama sebagai identitas pengguna kamus yang sedang menjalankan aplikasi Distory. Tombol masuk berfungsi untuk mengakses meu-menu di halaman home dan tombol keluar berfungsi untuk mengakhiri penggunaan aplikasi.

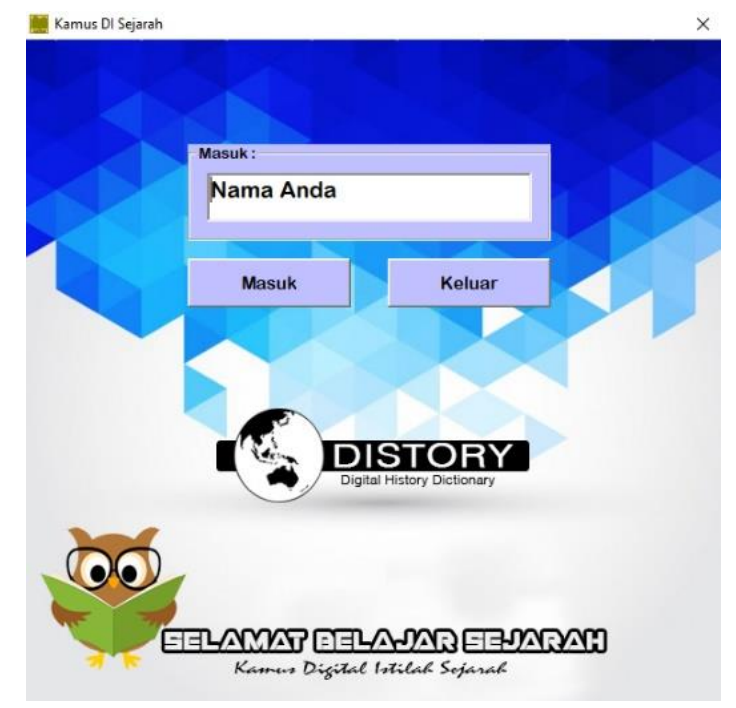

Gambar 3. Halaman awal distory (sumber: dokumen peneliti, 2021)

Halaman home terdapat tiga tombol atau menu yang terdiri dari a) menu kamus digital istilah sejarah, b) menu website pembelajaran (browser), dan c) tombol keluar. Menu kamus digital istilah sejarah berfungsi mencari materi dengan keywords materi yang ingin dipelajari. Khusus penelitian dan pengembangan saat ini materi yang di input dalam database terkait Kerajaan Tarumanegara sesuai dengan temuan masalah di lapangan. Terdapat dua kolom istilah/kata dan arti/definisi. Kolom istilah/kata sebagai kolom keywords materi yang ingin di pelajari, sedangkan arti/definisi memuat penjelasan atau materi dari keywords yang sedang dicari. 


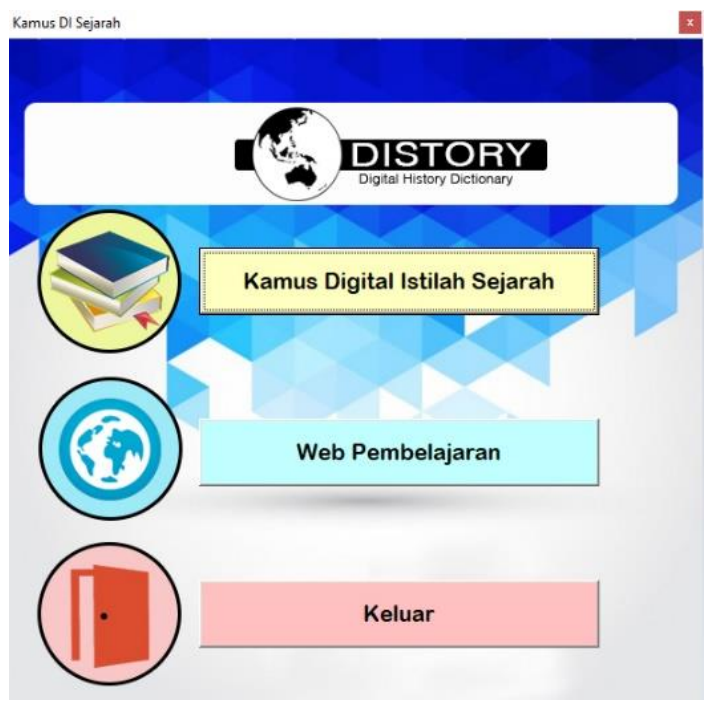

Gambar 4. Tampilan menu home (sumber: dokumen peneliti, 2021)

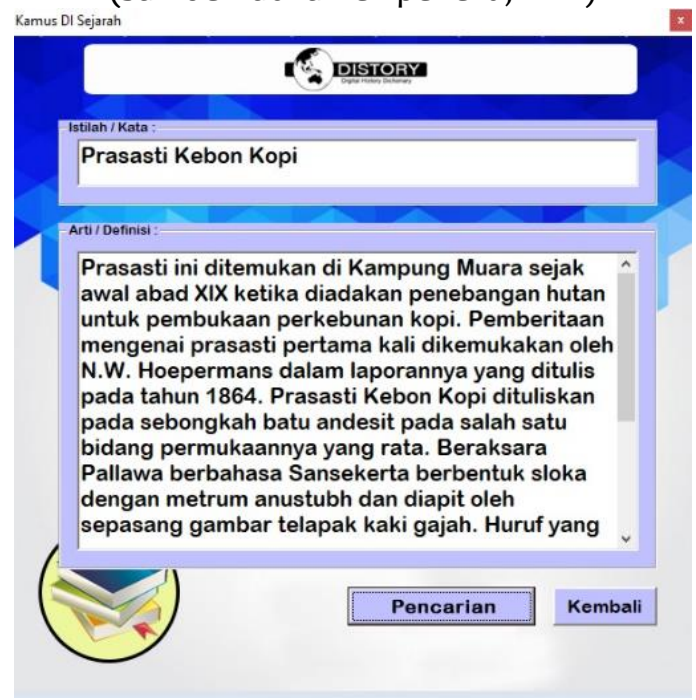

Gambar 5. Tampilan kamus

(sumber: dokumen peneliti, 2021)

Menu web pembelajaran yang merupakan browser khusus di program untuk laman-laman pendukung pembelajaran dan tidak bisa untuk browsing tema lain kecuali yang sudah tentukan seperti halnya website wikipedia, website perpustakaan nasional dan website museum nasional yang diakses secara online. Hal ini bertujuan untuk membantu peserta didik belajar fokus saat belajar secara mandiri ataupun bersama. 


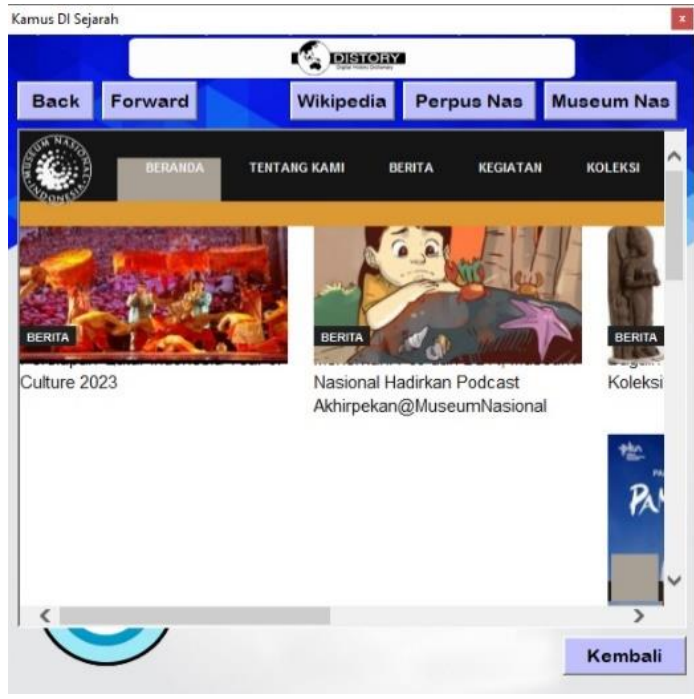

Gambar 6. Tampilan web pembelajaran (sumber: dokumen peneliti, 2021)

\section{Hasil Validasi dan Uji Coba Lapangan}

Pengembangan produk dilaksanakan sesuai 10 langkah research and development model Sugiyono. Validasi media sebagai dasar penyempurnaan produk sebelum dilaksanakan uji coba lapangan. Validasi media dilaksanakan pada tanggal 13 Februari 2021 oleh Bapak Muhammad 'Ariful Furqon, S.Pd., M.Kom Dosen Jurusan Sistem Informasi, Universitas Negeri Jember. Nilai rata-rata akhir diperoleh $85 \%$ yang menunjukkan sumber belajar dalam kategori sangat layak dan dapat diimplementasikan. Uji coba kelas kecil dilaksanakan dengan produk yang sudah direvisi berdasarkan penilaian, kritik dan saran ahli media yakni pada indikator jenis huruf dianjurkan dengan tidak terlalu formal atau kaku, ukuran huruf dengan font size 14, dan kemudahan pengoperasian.

Subjek coba kelas kecil dengan jumlah 10 peserta didik dari kelas X MIPA 4, Madrasah Aliyah Negeri (MAN) Kota Batu. Latar belakang pemilihan X MIPA 4 dikarenakan rata-rata nilai penugasan dibawah rata-rata nilai penugasan kelas lain. Pemilihan peserta uji coba kelas kecil berdasarkan ratarata nilai harian lima teratas dan lima terbawah di kelas X MIPA 4. Berikut prsentase hasil uji coba kelas kecil pada tanggal 15 Februari 2021:

Tabel 5. Persentase hasil uji coba kelas kecil

\begin{tabular}{clcc}
\hline No & \multicolumn{1}{c}{ Indikator } & Persentase (\%) & Keterangan \\
\hline 1 & Kemenarikan aplikasi kamus & $92,50 \%$ & Sangat layak \\
2 & Kesesuaian tampilan (warna, huruf dan tata letak) & $82,50 \%$ & Layak \\
3 & Kejelasan tampilan dan teks & $87,50 \%$ & Sangat layak \\
4 & Kemudahan aplikasi portable & $85,00 \%$ & Sangat layak \\
5 & Kemudahan pengoperasian & $82,50 \%$ & Layak \\
6 & Kemudahan mendapatkan informasi & $97,50 \%$ & Sangat layak \\
7 & Kemudahan menjalankan web pembelajaran & $82,50 \%$ & Layak \\
8 & Menambah motivasi belajar & $92,50 \%$ & Sangat layak \\
9 & Membantu proses belajar & $92,50 \%$ & Sangat layak \\
10 & Menambah referensi sumber belajar & $92,50 \%$ & Sangat layak \\
\hline \multicolumn{2}{r}{ Rata-rata } & $\mathbf{8 8 , 7 5 \%}$ & Sangat layak \\
\hline
\end{tabular}

(sumber: dokumen peneliti, 2021) 
Uji coba kelas kecil menunjukkan persentase akhir 88,75\% dan masuk kategori sangat layak. Berdasarkan data kualitatif (kritik dan saran) uji coba kelas kecil dilakukan evaluasi dan revisi produk terkait database. Sehingga aplikasi lebih mempermudah peserta didik mencari materi dengan keywords pada aplikasi Distory ke depannya. Evaluasi pada poin data kesesuaian warna, kemudahan pengoperasian, web pembelajaran juga menjadi fokus revisi. Warna diperbaiki sesuai usia peserta didik yang lebih tertarik dengan warna cerah. Kemudahan pengoperasian dilakukan perbaikan pada tata letak tombol menu dan navigasi, sedangkan web pembelajaran dirubah menjadi lebih minimalis.

Uji coba kelas besar dilaksanakan pada tanggal 17 Februari 2021 dengan subjek uji coba 30 peserta didik dari kelas X IPS 2, Madrasah Aliyah Negeri (MAN) Kota Batu. Pemilihan subjek kelas X IPS 2 dengan dasar kelas ini berisikan peserta didik yang aktif dalam berorganisasi. Sehingga terkadang mendapatkan dispensasi pembelajaran cukup sering. Hal ini dinilai sudah cukup tepat untuk mengukur kelayakan Distory sebagai sumber belajar mandiri ataupun bersama. Berikut persentase hasil uji coba kelas besar:

Tabel 6. Persentase hasil uji coba kelas besar

\begin{tabular}{clcc}
\hline No & \multicolumn{1}{c}{ Indikator } & Persentase (\%) & Keterangan \\
\hline 1 & Kemenarikan aplikasi kamus & $92,50 \%$ & Sangat layak \\
2 & Kesesuaian tampilan (warna, huruf dan tata letak) & $87,50 \%$ & Sangat layak \\
3 & Kejelasan tampilan dan teks & $87,50 \%$ & Sangat layak \\
4 & Kemudahan aplikasi portable & $87,50 \%$ & Sangat layak \\
5 & Kemudahan pengoperasian & $82,50 \%$ & Layak \\
6 & Kemudahan mendapatkan informasi & $92,50 \%$ & Sangat layak \\
7 & Kemudahan menjalankan web pembelajaran & $92,50 \%$ & Sangat layak \\
8 & Menambah motivasi belajar & $97,50 \%$ & Sangat layak \\
9 & Membantu proses belajar & $85,00 \%$ & Sangat layak \\
10 & Menambah referensi sumber belajar & $85,00 \%$ & Sangat layak \\
\hline \multicolumn{2}{r}{ Rata-rata } & $\mathbf{8 9 , 0 0 \%}$ & Sangat layak \\
\hline
\end{tabular}

(sumber: dokumen peneliti, 2021)

Berdasarkan hasil uji coba kelas besar yang menunjukkan nilai akhir rata-rata $89 \%$ yang masuk dalam kategori sangat layak. Temuan di uji coba kelas besar sudah tidak banyak, hanya perbaikan pada tombol menu-menu yang lebih disesuaikan tempatnya dan ukurannya. Berdasarkan hasil dari uji coba lapangan secara garis besar aplikasi Distory masuk kategori sangat layak dan siap diimplementasikan. Peningkatan dari hasil uji coba didukung faktor perbaikkan produk sebelumnya dari setiap poin-poin indikator. 


\section{PERBANDINGAN HASIL UJI COBA KECIL DAN BESAR BERDASARKAN POIN INDIKATOR}

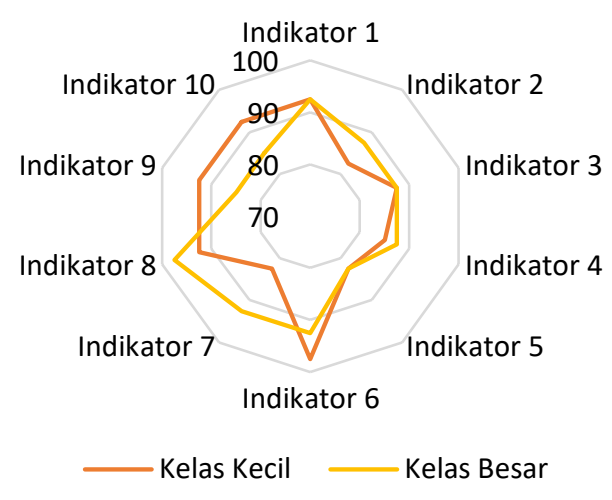

Gambar 6. Diagram perbandingan hasil uji coba lapangan (sumber: dokumen peneliti, 2021)

Berdasarkan diagram di atas dapat dibandingkan hasil uji coba kelas kecil dan kelas besar berdasarkan poin-poin indikator yang diisi oleh responden. Hasil uji coba dapat dilihat kenaikkan atau penurunan dari setiap poin indikator. Latar belakang kedua subjek coba juga memberi pengaruh terhadap hasil uji coba setiap poin indikatornya. Warna dan tampilan cenderung kearah selera setiap responden, namun secara garis besar aplikasi yang dikembangkan sudah layak sebagai sumber belajar. Sehingga tujuan utama menyediakan sumber belajar mandiri ataupun bersama yang memudahkan peserta didik dalam mencari materi dan tidak membosankan sudah tercapai. Kemandirian peserta didik diperlukan untuk mengarahkan dan mengendalikan dalam berfikir dan bertindak, sehingga tidak tergantung pada orang lain secara emosional (Hamzah, 2008). Kemandirian diharapkan memunculkan potensi dan cara berfikir kritis peserta didik. Berdasarkan data uji coba aplikasi Distory sudah dalam kategori sangat layak dan dapat diimplementasikan.

\section{SIMPULAN}

Distory dikonsep dan dikembangkan berdasarkan data observasi lapangan yang bertujuan untuk membantu belajar dan sebagai inovasi sumber belajar sejarah secara mandiri ataupun bersama. Sistem kamus membantu peserta didik untuk mendapatkan materi dengan cepat dan menjadi solusi kurangnya minat baca buku sejarah. Inovasi sumber belajar diperlukan sebagai solusi permasalahan dan mengurangi image pelajaran sejarah sebagai pelajaran hafalan. Aplikasi Distory sebagai sumber belajar berbasis digital yang telah melalui validasi ahli dan dua uji coba lapangan dengan hasil sangat layak. Selanjutnya aplikasi Distory dikembangkan dengan materi sejarah yang lebih kompleks dan menjadi salah satu pilihan sumber belajar sejarah untuk peserta didik. Untuk memaksimalkan aplikasi Distory ini secara berkelanjutan akan terus dilakukan peningkatan kualitas dan kuantitas dengan lebih baik menyesuaikan perkembangan ilmu pengetahuan dan teknologi. 


\section{DAFTAR RUJUKAN}

Buku dan Jurnal

Alim, M., \& Puspitasari, I. (2021). CIS-MAKOBA: INOVASI SELF MONITORING CATATAN IBADAH SISWA BERBASIS WEB. Proceeding Of International Conference On Islamic Education (ICIED), 5(1), 274 - 285. Retrieved from http://conferences.uinmalang.ac.id/index.php/icied/article/view/1257

Arikunto, S. (2006). Prosedur Peneltian. Suatu Pendekatan Praktek. Rineke Cipta.

Hamalik, O. (1994). Media Pendidikan, cetakan ke-7. Citra Aditya Bakti.

Musfiqon, H.M. (2012). Pengemabangan Media dan Sumber Pemebelajaran. Prestasi Pustaka

Prastowo, A. (2018). Sumber belajar dan pusat sumber belajar: Teori dan aplikasinya di sekolah/madrasah. Kencana.

Ramadani, S., \& Ofianto, O. (2019). Pengembangan Kamus Mnemonic sebagai Sumber Belajar Sejarah Indonesia di Sekolah Menengah Atas. Jurnal Halaqah, 1(2), 102-120.

Rusman. (2009). Manajemen kurikulum. Jakarta: Rajawali Pers.

Sanjaya, W. (f2011). Strategi Pembelajaran Berorientasi Standar Proses Pendidikan. Kencana

Sayono, J. (2015). Pembelajaran Sejarah di Sekolah: Dari Pragmatis ke Idealis. Jurnal Sejarah dan Budaya, 7(1), 9-17.

Sitepu, B.P. (2014). Pengembangan Sumber Belajar. RajaGrafindo Persada

Sugiyono. (2008). Metode penelitian pendidikan (Pendekatan kuatintatif, kualitatif dan R\&D). Alfabeta.

Hamzah, B. U. (2008). Teori motivasi dan pengukurannya. Bumi Aksara. 